\title{
Traumatic Brain Injury Alters the Molecular Fingerprint of TUNEL- Positive Cortical Neurons In Vivo: A Single-Cell Analysis
}

\author{
Dianne M. O’Dell, ${ }^{1}$ Ramesh Raghupathi, ${ }^{1}$ Peter B. Crino, ${ }^{2}$ James H. Eberwine, ${ }^{3}$ and Tracy K. Mclntosh ${ }^{1,3,4}$ \\ Departments of ${ }^{1}$ Neurosurgery, ${ }^{2}$ Neurology, and ${ }^{3}$ Pharmacology, University of Pennsylvania School of Medicine, \\ Philadelphia, Pennsylvania 19104, and 4Veterans Administration Medical Center, Philadelphia, Pennsylvania 19104
}

The cerebral cortex is selectively vulnerable to cell death after traumatic brain injury (TBI). We hypothesized that the ratio of mRNAs encoding proteins important for cell survival and/or cell death is altered in individual damaged neurons after injury that may contribute to the cell's fate. To investigate this possibility, we used amplified antisense mRNA (aRNA) amplification to examine the relative abundance of 31 selected candidate $\mathrm{mR}$ NAs in individual cortical neurons with fragmented DNA at 12 or $24 \mathrm{hr}$ after lateral fluid percussion brain injury in anesthetized rats. Only pyramidal neurons characterized by nuclear terminal deoxynucleotidyl transferase-mediated biotinylated dUTP nick end labeling (TUNEL) reactivity with little cytoplasmic staining were analyzed. For controls, non-TUNEL-positive neurons from the cortex of sham-injured animals were obtained and sub- jected to aRNA amplification. At $12 \mathrm{hr}$ after injury, injured neurons exhibited a decrease in the relative abundance of specific mRNAs including those encoding for endogenous neuroprotective proteins. By $24 \mathrm{hr}$ after injury, many of the mRNAs altered at $12 \mathrm{hr}$ after injury had returned to baseline (sham-injured) levels except for increases in caspase-2 and bax mRNAs. These data suggest that TBI induces a temporal and selective alteration in the gene expression profiles or "molecular fingerprints" of TUNEL-positive neurons in the cerebral cortex. These patterns of gene expression may provide information about the molecular basis of cell death in this region after TBI and may suggest multiple avenues for therapeutic intervention.

Key words: TUNEL; brain injury; gene expression; cell death; caspase; aRNA amplification
Several neuronal populations are selectively vulnerable to cell death after traumatic brain injury (TBI) in experimental models and in man (Adams, et al., 1983; Cortez et al., 1989; Kotapka et al., 1991, 1994; Lowenstein et al., 1992; Dietrich et al., 1994; Hicks et al., 1996; Bramlett et al., 1997). Both necrotic and apoptotic cell death have been described after experimental and clinical TBI (Dietrich et al., 1994; Rink et al., 1995; Colicos and Dash, 1996; Clark et al., 1997, 1999; Smith et al., 1997; Yakovlev et al., 1997; Conti et al., 1998). A common feature of both necrotic and apoptotic cell death is DNA fragmentation as determined by the terminal deoxynucleotidyl transferase-mediated biotinylated dUTP nick end labeling (TUNEL) method (Gavrieli et al., 1992).

Few studies have examined the molecular mechanisms underlying traumatically induced cell death. Increased expression of caspase- 1 and caspase- 3 mRNAs has been reported in the injured cortex $24 \mathrm{hr}$ after fluid percussion (FP) injury that correlated with apoptosis and behavioral dysfunction (Yakovlev et al., 1997). Both caspase- 1 and caspase- 3 protein levels are also increased in human brain after TBI (Clark et al., 1999). The bcl-2 family that includes several members either promoting or inhibiting cell death has been implicated in the molecular pathology of TBI. In

Received Feb. 16, 2000; revised April 12, 2000; accepted April 13, 2000.

This work was supported, in part, by the the National Institute of Neurological Disorders and Stroke Grant P50-NS08803, a National Institute of General Medical Sciences Grant RO1-GM34690, a Veterans Administration merit review grant (T.K.M.), a grant from the American Heart Association (P.B.C.), and the National Institute of Aging Grant RO1-AG9900 (J.H.E.). We thank Dr. Sharad Kumar for the caspase- 2 cDNA, Dr. Gerald Litwack for the caspase-3 cDNA, and Dr. Kenneth Strauss for the bcl-2, bcl- $x_{1}$, and bax cDNAs. We also thank Drs. Marc Dichter and John Trojanowski for critical review of this manuscript and Dr. Robert Hamm for consultation regarding statistical analysis.

Correspondence should be addressed to Dr. Tracy K. McIntosh, Department of Neurosurgery, University of Pennsylvania, 3320 Smith Walk, Room 105-C, Hayden Hall, Philadelphia, PA 19104. E-mail: mcintosh@seas.upenn.edu.

Copyright (C) 2000 Society for Neuroscience $0270-6474 / 00 / 204821-08 \$ 15.00 / 0$ particular, expression of bcl-2 protein has been shown to be a survival factor for cells after TBI (Clark et al., 1997; Raghupathi et al., 1998; Nakamura et al., 1999). In addition to the multiplicity of caspase and bcl-2 gene families, expression of several other classes of genes including neurotrophins, transcription factors, immediate-early genes, and cell cycle and stress response-related genes have been reported to be differentially expressed in the injured brain (Lowenstein et al., 1994; Hayes et al., 1995; Raghupathi et al., 1995; Yang et al., 1995, 1996; Napieralski et al., 1999). However, the analysis of multiple genes in vivo after TBI has not been performed.

Many of the methods used to measure gene expression changes in the injured brain [e.g., in situ hybridization or reverse transcriptase (RT)-PCR] lack the ability to detect multiple mRNAs within the same sample (Eberwine et al., 1992). Furthermore, assays that use tissue homogenates as starting material cannot define the cellular localization of gene expression changes because of the heterogeneous population of cells present within the sample. The amplified antisense mRNA (aRNA) technique circumvents these limitations by allowing the detection of multiple mRNAs within single cells in culture (Eberwine et al., 1992) or from fixed tissue (Crino et al., 1996), thus allowing a constellation of genes to be analyzed in individual cells. To investigate the multiple and temporal changes in gene expression that occur specifically in damaged cells after experimental TBI, we adapted the aRNA technique for use in histologically fixed TUNELpositive cells (O'Dell et al., 1998). As a marker of fragmented DNA, TUNEL has been used widely to characterize damaged cells after various brain insults including ischemia (FerrandDrake and Wieloch, 1999) and seizures (Roux et al., 1999; Tuunanen et al., 1999). Although TUNEL alone cannot distinguish between apoptotic or necrotic cell death, TUNEL along with 
morphological characterization can help to distinguish necrotic versus apoptotic cell death (Rink et al., 1995; Conti et al., 1998). We hypothesized that the expression of select candidate genes for cell survival or cell death may be different between injured neurons in the cerebral cortex and cortical neurons from uninjured animals and that the molecular profiles of TUNEL-positive cells may be temporally distinct. The pattern of gene expression between these populations of cells may provide clues as to the molecular mechanisms mediating selective neuronal cell death after TBI.

\section{MATERIALS AND METHODS}

Lateral fluid percussion brain injury. Adult male Sprague Dawley rats $(n=$ 12) weighing $350-400 \mathrm{gm}$ were used. Animals in the injured group $(n=$ 3 per time point) were anesthetized with sodium pentobarbital (60 $\mathrm{mg} / \mathrm{kg}$, i.p.). Rats were placed in a stereotaxic frame, the scalp and temporalis muscle were reflected, and a $3.0 \mathrm{~mm}$ craniectomy was made over the left parietal cortex midway between bregma and lambda. Rats were subjected to lateral FP brain injury of moderate severity (2.4-2.6 atm) as originally described (McIntosh et al., 1989). Briefly, a female Leur-Lok fitting was attached to the craniectomy site with cyanoacrylate adhesive. The animal is connected to the injury device that injects a rapid bolus of saline into the closed cranial cavity producing mechanical deformation of brain tissue (21-23 msec). Additional control (shaminjured) rats ( $n=3$ per time point) were surgically prepared and connected to the injury device but did not receive a fluid pulse.

Tissue preparation. Twelve or $24 \mathrm{hr}$ after FP injury and 12 or $24 \mathrm{hr}$ after sham injury, rats were reanesthetized with sodium pentobarbital $(200$ $\mathrm{mg} / \mathrm{kg}$, i.p.) and transcardially perfused with heparinized saline followed by $4 \%$ paraformaldehyde in $0.1 \mathrm{M}$ phosphate buffer, $\mathrm{pH}$ 7.6. All brains were post-fixed in the skull at $4^{\circ} \mathrm{C}$ for $3-4 \mathrm{hr}$ after perfusion. Subsequently, brains were removed from the skull and immersed in fixative for $24 \mathrm{hr}$ at $4^{\circ} \mathrm{C}$. After fixation, brains were embedded in paraffin and cut into $6 \mu \mathrm{m}$ sections on a microtome. We chose to examine gene expression in neurons from the brains of animals killed at $12 \mathrm{hr}$ after injury because this is the earliest time point at which the cells within injured brains are stained positive with TUNEL (Rink et al., 1995). All protocols were approved by the Institutional Animal Care and Use Committee of the University of Pennsylvania, and in all studies we adhered to the animal welfare guidelines set forth in the United States Department of Health and Human Services Guide for the Care and Use of Laboratory Animals.

TUNEL labeling. TUNEL was performed using previously described methods (Gavrieli et al., 1992; Rink et al., 1995). Briefly, $6 \mu \mathrm{m}$ coronal sections cut at 3.6-3.8 $\mathrm{mm}$ posterior to bregma were adhered to poly-Llysine-coated slides by brief heat treatment at $60^{\circ} \mathrm{C}$ for $15 \mathrm{~min}$. After deparaffinization and rehydration, the tissue was digested for $15 \mathrm{~min}$ in proteinase K (20 mg/ml; Sigma, St Louis, MO). The reaction was terminated with $\operatorname{tap} \mathrm{H}_{2} \mathrm{O}$, and the tissue was treated with buffer A (25 mmol/1 Tris, $\mathrm{pH} 6.6$, containing $200 \mathrm{mmol} / 1$ potassium cacodylate and $0.25 \mathrm{mg} / \mathrm{ml}$ bovine serum albumin) for at least $5 \mathrm{~min}$. Sections were incubated at $37^{\circ} \mathrm{C}$ with labeling solution containing Tdt $(0.3 \mathrm{U} / \mathrm{ml}$; Boehringer Mannheim, Indianapolis, IN), biotinylated-16-dUTP (20 $\mathrm{mmol} / \mathrm{l}$; Boehringer Mannheim), and $1.5 \mathrm{mmol} / \mathrm{l}$ cobalt chloride in buffer $\mathrm{A}$ for $1 \mathrm{hr}$ in a humidified chamber. The reaction was terminated with $2 \times$ SSC $(300 \mathrm{~mm}$ sodium chloride and $30 \mathrm{~mm}$ sodium citrate, $\mathrm{pH}$ 7.4). After vigorous washing with $0.1 \mathrm{M}$ Tris, $\mathrm{pH} 7.4$, the sections were blocked with $10 \%$ goat serum in $0.1 \mathrm{~m}$ Tris for $15 \mathrm{~min}$. The DNA was visualized by treating the tissue with a 1:40 dilution of streptavidinconjugated alkaline phosphatase (BioGenex, San Ramon, CA) and staining with fast red (Sigma). Sections were stored in diethylpyrocarbonate (DEPC)-treated distilled $\mathrm{H}_{2} \mathrm{O}$ until further processing.

In situ transcription. After TUNEL, sections were placed in a humidified chamber and incubated in 50\% formamide, DEPC-treated distilled $\mathrm{H}_{2} \mathrm{O}$, and an oligo-dT primer coupled to a T7 RNA polymerase promoter sequence (oligo-dT-T7) for 12-18 hr at room temperature. The cDNA was synthesized directly on the section using the oligo-dT-T7 as a primer for the poly $\left(\mathrm{A}^{+}\right)$tail mRNA population and the avian myeloblastosis virus reverse transcriptase $(0.5 \mathrm{U} / \mathrm{ml}$; Seikagaku America, Falmouth, MA) in reaction buffer [50 mM Tris $\mathrm{HCl}, \mathrm{pH} 8.3,6 \mathrm{mM} \mathrm{MgCl}_{2}, 120 \mathrm{~mm}$ $\mathrm{KCl}, 7 \mathrm{~mm}$ dithiothreitol, $250 \mathrm{~mm}$ each dATP, dCTP, dGTP, and TTP, and $0.12 \mathrm{U} / \mathrm{ml}$ RNAsin (Promega, Madison, WI)]. After synthesis, the sections were washed for $8-12 \mathrm{hr}$ in $0.5 \times$ SSC.

Single-cell $m R N A$ amplification. After TUNEL and in situ transcription
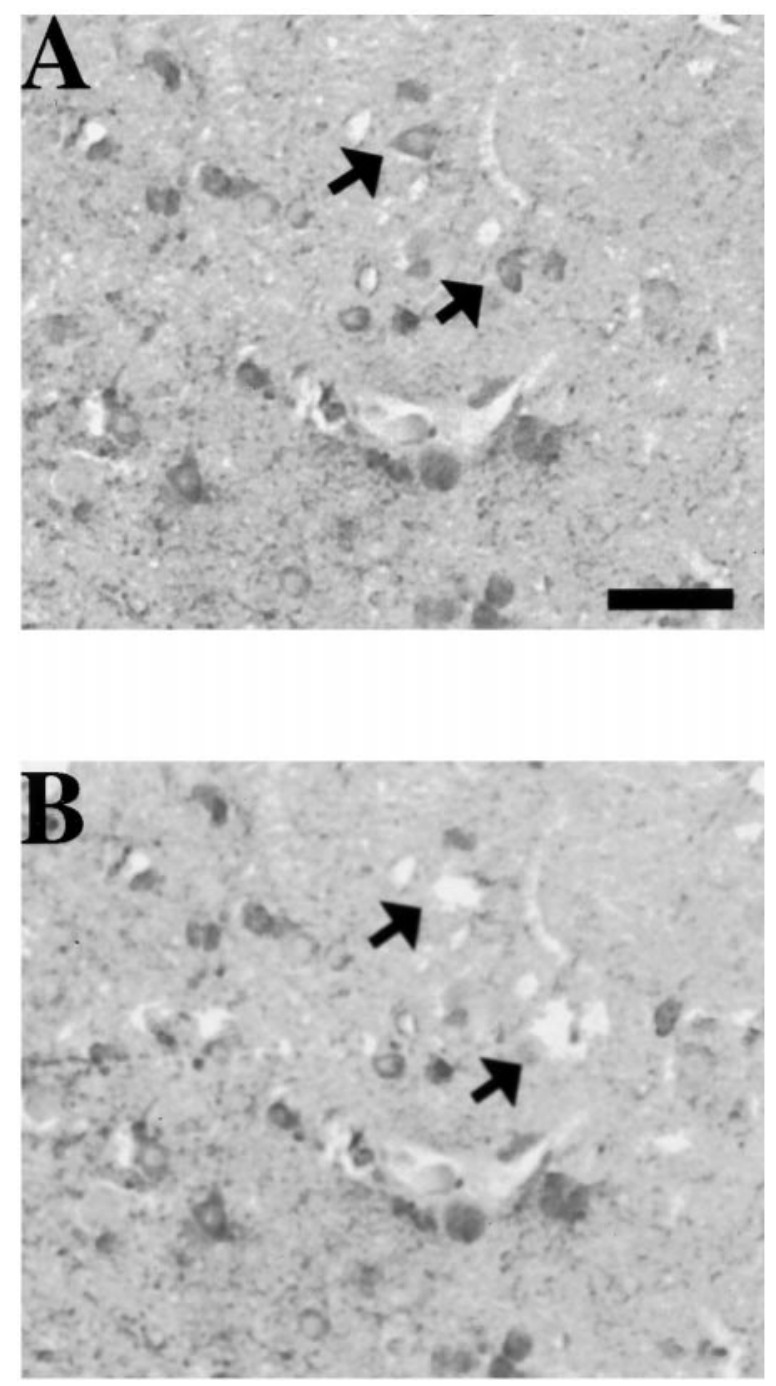

Figure 1. A, Photomicrograph of two TUNEL-positive cells (arrows) from the cerebral cortex of a rat after lateral FP brain injury. Note the triangular morphology of the cell selected for aRNA amplification (top arrow). B, Photomicrograph of the same cells (arrows) shown in $A$ after dissection and aspiration from the section. Note that adjacent cells remain intact. In both $A$ and $B$, the sections were viewed without coverslips and photographed while under water. Scale bar, $75 \mu \mathrm{m}$.

(IST), individual TUNEL-positive neurons from the cortex (layers 4-5) ipsilateral to the impact site of injured brains $(n=3$ cells per brain) were viewed (uncoverslipped) under $40 \times$ magnification, dissected away from the tissue section by using an attached micromanipulator, and aspirated gently into glass microelectrodes (Crino et al., 1996). Only pyramidal neurons (characterized by a triangular shape and the presence of at least one dendrite) exhibiting nuclear TUNEL staining and little cytoplasmic staining were aspirated (see Fig. 1). Although TUNEL is a marker for DNA damage, we chose to evaluate gene expression changes after TBI in TUNEL-positive neurons exhibiting a nonapoptotic morphology (characterized by intense nuclear staining, little or diff use cytoplasmic staining, and retention of triangular shape, the neuronal-type morphology) for two reasons: (1) the shrunken and condensed appearance of apoptotic cells precludes the distinction of neuronal versus non-neuronal cells, and (2) apoptotic cells with the classic appearance of apoptotic bodies may indicate irreversible damage. In addition, non-TUNEL-positive pyramidal neurons ( $n=2$ per brain) from the same cortical region used previously for selecting TUNEL-positive neurons from injured animals were identified by phase-contrast microscopy and aspirated. NonTUNEL-positive pyramidal neurons from sham-injured rats killed at 24 hr after injury ( $n=3$ per brain) were identified by phase-contrast microscopy and aspirated. Additional non-TUNEL-positive pyramidal 
neurons from sham-injured rats killed at $12 \mathrm{hr}$ after injury ( $n=2$ neurons per brain) were identified by phase-contrast microscopy and aspirated.

The mRNA from individual neurons was amplified according to previously described methods (Eberwine et al., 1992; Crino et al., 1996). After aspiration of the cellular contents, the single-stranded cDNA was heat denatured at $95^{\circ} \mathrm{C}$ for $5 \mathrm{~min}$. Single-stranded cDNA was made double-stranded by incubation with dNTPs, T4 DNA polymerase, and the Klenow fragment of DNA polymerase I for $12 \mathrm{hr}$ at $14^{\circ} \mathrm{C}$. The hairpin loop of the cDNA was then excised with $\mathrm{S} 1$ nuclease at $37^{\circ} \mathrm{C}$ for $5 \mathrm{~min}$. The ends of the double-stranded cDNA were made blunt with T4 DNA polymerase at $37^{\circ} \mathrm{C}$ for $15 \mathrm{~min}$. To remove free dNTPs, the cDNA was drop-dialyzed against $50 \mathrm{ml}$ of RNase-free $\mathrm{H}_{2} \mathrm{O}$ for $4 \mathrm{hr}$. Approximately $20 \%$ of the dialyzed product was amplified with T7 RNA polymerase (Epicentre Technologies, Madison, WI) incorporating [ $\left.{ }^{32} \mathrm{P}\right] \mathrm{CTP}$. The aRNA (amplified antisense mRNA) served as a template for secondround cDNA synthesis that served as a template for a second aRNA amplification incorporating $\left[{ }^{32} \mathrm{P}\right] \mathrm{CTP}$. This final radiolabeled aRNA was used to probe reverse Northern (slot) blots.

Reverse Northern blot. To detect particular mRNAs present in single TUNEL-positive neurons and unlabeled neurons, reverse Northern blotting was performed with linearized plasmid cDNAs. All cDNAs were sequenced to confirm their identity. Nylon membranes (Hybond-N, Arlington Heights, IL) were made wet with DEPC-treated distilled $\mathrm{H}_{2} \mathrm{O}$ and $10 \times$ SSC. Each cDNA $(0.5 \mu \mathrm{g})$ was heat denatured at $95^{\circ} \mathrm{C}$ for 10 min and applied by gravity to nylon membranes. The cDNAs were bound to the membranes by UV cross-linking. We chose an array of cDNAs that would reflect a sample of the mRNAs found in these neurons plus specific cDNAs representing a panel of procell-death and anticell-death genes. The cDNAs included pBluescript (pBs), glial fibrillary acidic protein (GFAP), low-molecular weight neurofilament (NF-L), calcium- and calmodulin-dependent kinase (CamKII), GAPDH, $\beta 2$ microglobulin $(\beta 2 \mathrm{M})$, cAMP response element-binding protein (CREB), $\mathrm{c}$-fos, glutamic acid decarboxylase (GAD65), subunits of the $\mathrm{GABA}_{\mathrm{A}}$ receptor ( $\beta 1$ and $\beta 2$ ), the AMPA receptor subunit (GluR2), the RNA-editing enzyme for GluR2, double-stranded specific editase1 (RED1), NMDA receptor subunits (NR1, NR2A, and NR2C), nerve growth factor (NGF), brainderived neurotrophic factor (BDNF), basic fibroblast growth factor (bFGF), tyrosine kinase receptors (trkA and trkB), bcl-2, bcl- $x_{1}$, bax, caspase-2, caspase-3, cyclooxygenase-2 (Cox-2), interleukin-6 (IL-6), superoxide dismutase (SOD1), tau, and redox factor (Ref-1). Blots were first incubated in prehybridization solution containing 50\% formamide, $6 \times$ standard saline, phosphate, and EDTA, $5 \times$ Denhardt's solution, 200 $\mu \mathrm{g} / \mathrm{ml}$ salmon sperm DNA, and $0.1 \%$ SDS for $8 \mathrm{hr}$ at $42^{\circ} \mathrm{C}$. Blots were then probed with $\left[{ }^{32} \mathrm{P}\right] \mathrm{CTP}$-labeled aRNA from individual neurons (one aRNA probe per blot) and hybridized at $42^{\circ} \mathrm{C}$ for $48 \mathrm{hr}$. Blots were then washed for $1 \mathrm{hr}$ in $2 \times \mathrm{SSC}$ and $0.1 \%$ SDS followed by two $30 \mathrm{~min}$ washes in $0.2 \times$ SSC and $0.1 \%$ SDS. Blots were dried briefly and apposed to film for $24 \mathrm{hr}$ followed by a $2 \mathrm{~d}$ exposure to a PhosphorImager screen.

Statistical analysis. The intensity of the autoradiographic signal corresponding to each cDNA was analyzed by a PhosphorImager using IMAGEQUANT software (Molecular Dynamics, Sunnyvale, CA). For each blot, pBs was used as the background value, and the expression of GFAP was a marker of glial contamination. The signal of the probe bound to each cDNA (minus the background value) was expressed as a percentage of the signal for the $\beta 1$ subunit of the $\mathrm{GABA}_{\mathrm{A}}$ receptor that served as an internal reference value. This value was chosen because the expression of $\beta 1$ was present in all neurons examined. A one-way ANOVA was used to analyze mean differences in gene expression for each gene among the three groups. To control for the experimentwise error associated with the multiple univariate ANOVAs performed, a Bonferroni correction was applied to each univariate ANOVA. This adjustment lowers the $p$ value required for statistical significance for each ANOVA, thus making the criterion for achieving statistical significance more stringent than if a correction factor were not used. If a significant difference was detected with the Bonferroni-adjusted ANOVA, individual post hoc comparisons were made using the Newman-Keuls test. A $p$ value of $<0.05$ was considered significant.

\section{RESULTS}

The cortex ipsilateral to the impact site exhibited many TUNELpositive cells with varying staining intensities at both 12 and $24 \mathrm{hr}$ after injury. The molecular profiles of non-TUNEL-positive pyramidal neurons from the cortex of injured animals were varied and exhibited no consistent pattern of gene expression (data not
A
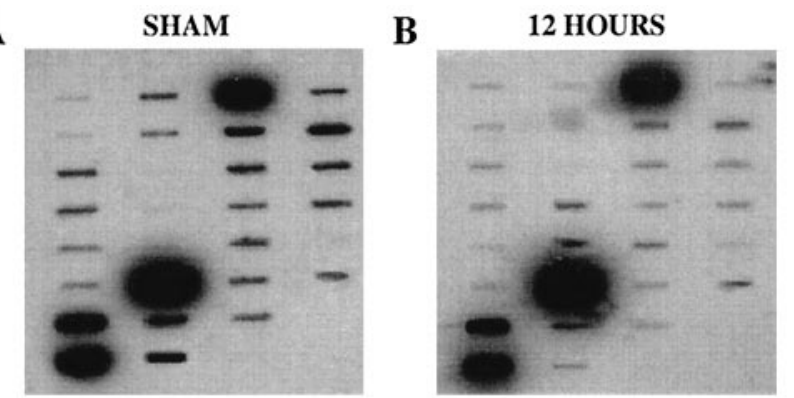

C

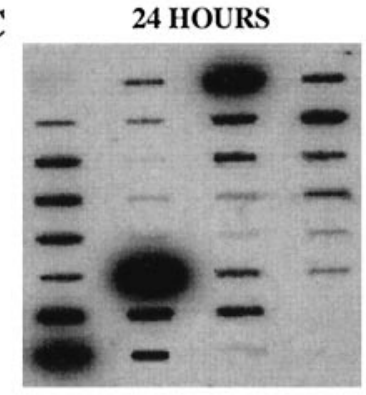

D

$\begin{array}{llll}\text { pBs } & \text { GluR2 } & \text { trkA } & \text { Cox-2 } \\ \text { GAPDH } & \text { RED-1 } & \text { trkB } & \text { SOD1 } \\ \text { B2M } & \text { NR1 } & \text { IL-6 } & \text { Ref-1 } \\ \text { CREB } & \text { NR2A } & \text { bcl-2 } & \text { CamKII } \\ \text { c-fos } & \text { NR2C } & \text { bcl-x } 1 & \text { tau } \\ \text { GAD65 } & \text { bFGF } & \text { bax } & \text { NF-L } \\ \text { B1 } & \text { NGF } & \text { caspase-2 } & \text { GFAP } \\ \text { B2 } & \text { BDNF } & \text { caspase-3 } & ----\end{array}$

Figure 2. Representative expression profiles from an unlabeled cortical neuron after sham injury $(A)$, a TUNEL-positive neuron from the cortex ipsilateral to the impact site $12 \mathrm{hr}$ after FP injury $(B)$, and a TUNELpositive neuron from the same cortical region $24 \mathrm{hr}$ after injury $(C)$. Note the differential mRNA abundances among the three neurons. The order of cDNAs is shown in $D$.

shown). Therefore, in all studies reported in this paper, we used only TUNEL-positive pyramidal neurons from the cortex of injured animals to identify cells with DNA fragmentation positively. Without a specific marker, non-TUNEL-positive cells within the injured cortex may represent a population of damaged cells that do not yet display DNA fragmentation. Alternatively, these cells may represent a population of healthy cells present within the injured cortex.

For comparison, we amplified the mRNA from non-TUNELpositive pyramidal neurons from the cortex of sham-injured animals at both 12 and $24 \mathrm{hr}$ after injury. The molecular profiles of the six non-TUNEL-positive cortical neurons taken from shaminjured animals at $12 \mathrm{hr}$ after injury did not differ from the molecular profiles of the nine non-TUNEL-positive pyramidal neurons taken from sham-injured brains at $24 \mathrm{hr}$ after injury (data not shown). This suggests that the long half-life of sodium pentobarbital did not induce any significant changes in gene expression in sham-injured rats at either time point (12 vs $24 \mathrm{hr}$ ). Consequently, only non-TUNEL-positive pyramidal neurons from the cortex of sham-injured animals at $24 \mathrm{hr}$ after sham injury were used as control neurons for gene expression. TBI resulted in different hybridization intensities for various mRNAs in TUNEL-positive cortical, pyramidal neurons at 12 or $24 \mathrm{hr}$ after injury compared with non-TUNEL-positive cortical, pyramidal neurons from the cortex of sham-injured animals at $24 \mathrm{hr}$ after injury (see Figs. 2, 3, 4).

\section{Housekeeping mRNAs}

At 12 or $24 \mathrm{hr}$ after injury, no significant differences were observed in the relative abundance of mRNAs for GAPDH or $\beta 2$ microglobulin between TUNEL-positive neurons and nonTUNEL-positive neurons from sham-injured animals ( $p, \mathrm{NS})$. 
Figure 3. Graphic representation of the mRNA abundances [divided into four classes including mRNAs associated with cell survival and repair $(A)$, cell death and inflammation $(B)$, and neurotransmitter regulation and receptor subunits $(C)$ and transcription factor, IEG, and cytoskeletal mRNAs $(D)]$ of the three groups shown in Figure 2. Data presented are the mean $( \pm$ SEM) and are represented as relative to the abundance of $\beta 1$ mRNA. Bars not shown have an expression level of zero. The filled bars represent the sham group, the open bars represent the $12 \mathrm{hr}$ group, and the dotted bars represent the $24 \mathrm{hr}$ group of neurons. An asterisk (*) above the sham bars indicates significance ( $p<0.05 \mathrm{vs}$ the $12 \mathrm{hr}$ group), a plus sign $(+)$ above the sham bars indicates significance ( $p<0.05$ vs the $24 \mathrm{hr}$ group), and a number sign (\#) above the $24 \mathrm{hr}$ bars indicates significance ( $p<0.05$ vs the $12 \mathrm{hr}$ group). Note that in $A$ the actual means for bFGF and trkA for the three groups are given. In $C$ the actual means for $\beta 2$ for the three groups are given. These means are also expressed relative to the abundance of $\beta 1$ mRNA.
A) Cell Survival/Repair

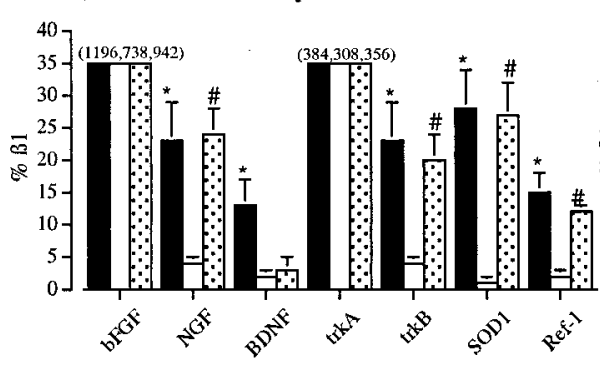

B) Cell Death/Inflammation

C) Neurotransmitter Regulation/Receptor Subunits

D) Transcription Factor/IEG/Cytoskeletal
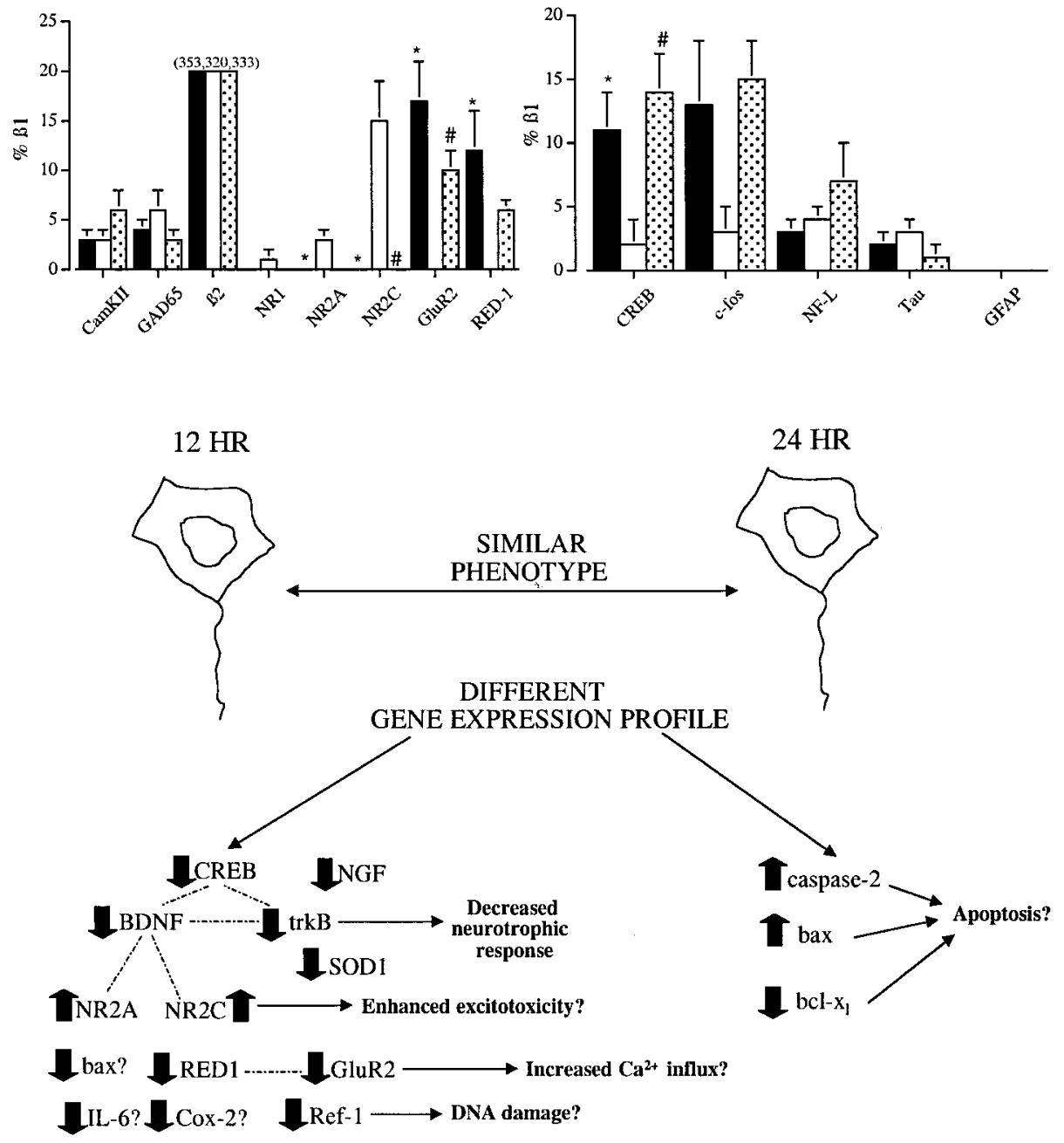

Figure 4. Diagram illustrating the different patterns of gene expression observed in phenotypically similar TUNEL-positive neurons after TBI, the interrelationships among different genes, and possible consequences of these changes. At $12 \mathrm{hr}$, TBI induced a decrease in the expression of many genes (thick downward arrows) with the exception of increases in NR2A and NR2C mRNAs (thick upward arrows). At $24 \mathrm{hr}$, most of the changes observed at $12 \mathrm{hr}$ had returned to control levels except for increases in caspase-2 and bax (thick upward arrows) and a decrease in bcl- $\mathrm{x}_{1}$ (thick downward arrow). Dotted lines indicate connections between genes, whereas solid lines with arrows indicate possible consequences of changes in the expression of particular genes. All changes in gene expression direction (up vs down) are versus the relative level in unlabeled cortical neurons from sham-injured animals.

\section{Cell survival and repair mRNAs \\ Neurotrophins}

The relative abundance of NGF mRNA was significantly decreased in TUNEL-positive neurons at $12 \mathrm{hr}$ after injury compared with non-TUNEL-positive neurons from sham-injured brains (Fig. $3 A ; p<0.05$ ). By $24 \mathrm{hr}$ after injury, the relative level of NGF mRNA in TUNEL-positive neurons had returned to sham-injured values ( $p$, NS) but remained elevated compared with that in TUNEL-positive neurons at $12 \mathrm{hr}$ after injury (Fig. $3 A ; p<0.05)$. No changes were observed in the mRNA abundance for trkA in TUNEL-positive neurons at any time point compared with non-TUNEL-positive neurons from sham-injured brains (Fig. $3 A$; $p$, NS). Injury-induced decreases in both BDNF $(p<0.05)$ and trkB $(p<0.05)$ mRNAs were observed at $12 \mathrm{hr}$ after injury in TUNEL-positive neurons compared with the relative level of these gene transcripts in non-TUNEL-positive neurons from sham-injured brains (Fig. 3A). By $24 \mathrm{hr}$ after injury, the levels of both of these mRNAs had returned to values obtained from non-TUNEL-positive neurons in sham-injured brains (Fig. $3 A$; $p$, NS). The mRNA abundance for trkB at $24 \mathrm{hr}$ after injury was increased when compared with that in TUNELpositive neurons at $12 \mathrm{hr}$ after injury (Fig. $3 A ; p<0.05$ ). Relative levels of bFGF mRNA were comparable between TUNELpositive neurons of injured brains at either time point and non-TUNEL-positive neurons from sham-injured brains (Fig. $3 A ; p$, NS). 


\section{Reparative enzymes}

Brain injury induced a significant decrease in SOD1 and Ref-1 mRNAs in TUNEL-positive neurons at 12 hr after injury compared with that in non-TUNEL-positive neurons from shaminjured brains (Fig. $3 A ; p<0.05$ ) that returned to baseline (sham-injured) levels by $24 \mathrm{hr}$ after injury (Fig. $3 A$; $p$, NS). Both of these mRNAs were increased in abundance at $24 \mathrm{hr}$ after injury in TUNEL-positive neurons when compared with the levels in TUNEL-positive neurons at $12 \mathrm{hr}$ after injury (Fig. 3A; $p<0.05)$.

\section{Cell death and inflammation-associated mRNAs bcl-2 family}

The relative levels of bcl- 2 mRNA did not change as a result of injury at either time point in TUNEL-positive neurons compared with non-TUNEL-positive neurons from sham-injured brains (Fig. $3 B ; p$, NS). The abundance of bcl- $\mathrm{x}_{1}$ mRNA was also unchanged between TUNEL-positive neurons at $12 \mathrm{hr}$ after injury and non-TUNEL-positive neurons from sham-injured brains (Fig. $3 B ; p$, NS). By $24 \mathrm{hr}$ after injury, however, the level of bcl- $\mathrm{x}_{1}$ mRNA was significantly decreased in TUNEL-positive neurons compared with non-TUNEL-positive neurons from sham-injured brains (Fig. $3 B ; p<0.05$ ). Relative levels of bax mRNA were decreased in TUNEL-positive neurons from injured brains at 12 hr after injury compared with non-TUNEL-positive neurons from sham-injured brains (Fig. $3 B ; p<0.05$ ). Interestingly, at 24 hr after injury, bax mRNA levels were found to be increased in TUNEL-positive neurons compared with TUNEL-positive neurons at $12 \mathrm{hr}$ after injury or non-TUNEL-positive neurons from sham-injured brains (Fig. $3 B ; p<0.05$ ).

\section{Caspase family}

The relative levels of caspase- 2 mRNA were not significantly different between TUNEL-positive neurons at $12 \mathrm{hr}$ after injury and non-TUNEL-positive neurons from sham-injured brains (Fig. 3B; $p$, NS). However, caspase-2 mRNA levels became significantly increased in TUNEL-positive neurons at $24 \mathrm{hr}$ after injury compared with non-TUNEL-positive neurons from shaminjured brains $(p<0.05)$ or TUNEL-positive neurons at $12 \mathrm{hr}$ after injury (Fig. $3 B ; p<0.05$ ). No significant differences were observed in caspase-3 mRNA levels between TUNEL-positive neurons at either time point and non-TUNEL-positive neurons from sham-injured brains (Fig. $3 B ; p$, NS).

\section{Inflammation-associated $m R N A s$}

At 12 hr after injury, the relative abundances of IL-6 and Cox-2 mRNAs were significantly decreased in TUNEL-positive neurons compared with non-TUNEL-positive neurons from shaminjured brains (Fig. 3B; $p<0.05$ ). By $24 \mathrm{hr}$ after injury, the relative abundances of IL- 6 and Cox- 2 mRNAs were not significantly different than baseline levels ( $p$, NS), but the relative levels of these mRNAs were significantly increased compared with the relative level in TUNEL-positive neurons at $12 \mathrm{hr}$ after injury (Fig. $3 B ; p<0.05$ ).

\section{Neurotransmitter synthesis, regulation, and receptor subunit mRNAs}

\section{Neurotransmitter regulation}

No alterations were observed after TBI in CamKII mRNA in TUNEL-positive neurons at any post-injury time point (Fig. $3 C$; $p$, NS).

\section{$G A B A$}

Brain injury did not alter the relative levels of GAD65 or the $\beta 2$ subunit of the $\mathrm{GABA}_{\mathrm{A}}$ receptor $\mathrm{mRNA}$ in TUNEL-positive neurons at any post-injury time point (Fig. $3 C$; $p$, NS).

\section{NMDA receptor}

No differences in NR1 subunit mRNA levels were observed at any time point in TUNEL-positive neurons from injured brains compared with non-TUNEL-positive neurons from sham-injured brains (Fig. 3C; $p$, NS). However, both NR2A $(p<0.05)$ and NR2C $(p<0.05)$ subunit mRNA levels were increased at $12 \mathrm{hr}$ after injury in TUNEL-positive neurons compared with nonTUNEL-positive neurons from sham-injured brains (Fig. $3 C ; p<$ $0.05)$. By 24 hr after injury, relative mRNA levels of these receptor subunits had returned to baseline levels (Fig. 3C). However, levels of NR2C mRNA were also elevated at $12 \mathrm{hr}$ after injury compared with that at $24 \mathrm{hr}$ after injury (Fig. $3 C ; p<0.05$ ).

\section{AMPA receptor}

At $12 \mathrm{hr}$ after injury, a significant decrease was observed in the relative abundance of GluR2 and RED1 mRNAs in TUNELpositive neurons compared with non-TUNEL-positive neurons from sham-injured brains (Fig. $3 C ; p<0.05$ ). By $24 \mathrm{hr}$ after injury, levels of GluR2 mRNA were significantly increased in abundance in TUNEL-positive neurons compared with the levels in TUNEL-positive neurons at $12 \mathrm{hr}$ after injury $(p<0.05)$ but were not significantly different from sham-injured levels (Fig. 3C; $p$, NS). Also, relative levels of RED1 mRNA in TUNEL-positive neurons at $24 \mathrm{hr}$ after injury had returned to baseline levels (Fig. $3 C ; p$, NS).

\section{Transcription factor, IEG, and cytoskeletal mRNAs Transcription factor}

At $12 \mathrm{hr}$ after injury, CREB mRNA levels were significantly decreased in TUNEL-positive neurons compared with the relative levels in non-TUNEL-positive neurons from sham-injured animals (Fig. 3D; $p<0.05$ ). By $24 \mathrm{hr}$ after injury, CREB mRNA levels in TUNEL-positive neurons were not significantly different from these levels in sham-injured animals ( $p$, NS) but were significantly increased compared with the levels in TUNELpositive neurons at $12 \mathrm{hr}$ after injury (Fig. $3 D ; p<0.05$ ).

\section{IEG}

No differences were observed at any time point in the abundance of c-fos mRNA between TUNEL-positive neurons from the injured brain and non-TUNEL-positive neurons from shaminjured brains (Fig. 3D; $p$, NS).

\section{Cytoskeletal mRNAs}

No changes were observed in the mRNA abundance for NF-L, tau, or GFAP in TUNEL-positive neurons after TBI (Fig. 3D; $p$, NS). The expression of GFAP was not detected in any cell.

\section{DISCUSSION}

We examined the expression of 31 selected candidate genes in individual TUNEL-positive neurons from the cortex of braininjured rats and compared these expression profiles with those of non-TUNEL-positive cortical neurons from sham-injured brains. Because of the differential molecular profiles that we observed in non-TUNEL-positive neurons from injured brains, TUNEL provided an unambiguous phenotypic marker of cell damage and/or DNA fragmentation. The injury-induced temporal changes in the molecular profiles of TUNEL-positive neurons at both 12 and 24 
hr after injury suggest that phenotypically identical cells can have different "molecular fingerprints." At $12 \mathrm{hr}$ after injury, significant decreases in mRNAs for specific genes (CREB, NGF, BDNF, trkB, SOD1, IL-6, GluR2, RED1, Ref-1, Cox-2, and bax) were observed in injured neurons, while others (c-fos, trkA, bFGF, bcl-2, caspase-2, caspase-3, NR1, $\beta 1, \beta 2$, CamKII, GAD65, tau, and NF-L) were unchanged, suggesting that decreases in these particular mRNAs observed in TUNEL-positive neurons were not the result of injury-induced transcriptional impairment.

Although Dash et al. (1995) observed an increase in phosphorylated CREB protein in the hippocampus 5 min after cortical impact injury that correlated with spatial memory deficits, our results showed a decrease in CREB mRNA by $12 \mathrm{hr}$ after injury. After ischemia, vulnerable CA1 hippocampal cells lose CREB immunoreactivity, whereas resistant cortical and dentate granule cells upregulate CREB protein (Walton et al., 1996). Furthermore, Walton et al. (1999) have shown that upregulation of CREB protein inhibited apoptosis in neurons, implicating increased CREB protein levels as a survival factor for neurons. Thus, the decrease in CREB mRNA in damaged neurons in the present study may be detrimental for cell survival, and this finding warrants further investigation.

An important consequence of the decrease in the relative abundance of CREB mRNA in injured neurons may be decreases observed in the expression of two target genes of CREB-BDNF and its receptor trkB (Courtney et al., 1997). Both BDNF and trkB have CRE elements (Shieh et al., 1998; Tao et al., 1998), and their expression may be mediated by CREB (Nibuya et al., 1996). Because BDNF has been shown to be neuroprotective in in vitro and in vivo models of excitotoxicity and ischemia (Kume et al., 1997; Schabitz et al., 1997), decreased BDNF mRNA could represent the reduction of an endogenous neuroprotective factor in injured cortical neurons. Our results are consistent with those of Hicks et al. (1999) who reported decreases in BDNF and trkB mRNAs in the contused cortex of rats after lateral FP injury. Interestingly, the downregulation of trkB observed in TUNELpositive cells in the present study may explain the lack of behavioral or histological protection after BDNF administration to brain-injured rats (Blaha et al., 2000). BDNF may exert its neuroprotective effects, in part, via downregulation of NMDA receptor function, and application of BDNF to cultured cerebellar granule cells has been shown to result in a downregulation of NR2A and NR2C mRNAs (Brandoli et al., 1998). The decrease in BDNF mRNA observed at $12 \mathrm{hr}$ after injury may have influenced the increases in NR2A and NR2C mRNAs observed during the same time after injury. This increased expression of the NR2A subunit of glutamate receptors may exacerbate the post-traumatic injury process because mice deficient in the NR2A subunit show a reduced infarct volume after focal ischemia (Morikawa et al., 1998). Our studies also demonstrated a decrease in GluR2 and RED1 mRNAs at $12 \mathrm{hr}$ after injury. The GluR2 subunit is subject to RNA editing by RED1 that edits the site in GluR2 pre-mRNA that determines the $\mathrm{Ca}^{2+}$ permeability of the channel (Melcher et al., 1996). Decreases in GluR2 mRNA have been documented previously in the hippocampus after ischemia (Pellegrini-Giampietro et al., 1992; Gorter et al., 1997) with no change in GluR2 editing (Rump et al., 1996). The decrease in both of these mRNAs in TUNEL-positive neurons in the present study may lead to increased $\mathrm{Ca}^{2+}$ influx through AMPA receptors and further enhance glutamate-mediated excitotoxicity.

Decreased mRNA abundance for NGF was also observed in injured neurons at $12 \mathrm{hr}$ after injury. A number of studies have demonstrated the neuroprotective effects of NGF after fimbriafornix lesions (Whittemore et al., 1991) or TBI (Sinson et al., 1995, 1997; Dixon et al., 1997). Thus, the decrease in NGF mRNA in injured neurons may contribute to post-traumatic cell death. Interestingly, trkA expression was unchanged by TBI, and this may help to explain the success of NGF therapy after brain trauma. Although our results do not support previous studies describing an increase in NGF mRNA in the cortex after TBI (DeKosky et al., 1994), these previous studies used a large cortical region as the source of RNA that may have included astrocytes, a major source of NGF mRNA observed after TBI (Goss et al., 1998). Interestingly, relative levels of IL-6 mRNA were also decreased in TUNEL-positive cortical neurons at $12 \mathrm{hr}$ after injury. Cytokines can affect the injury process by modulating the synthesis of neurotrophins (Morganti-Kossmann et al., 1997), and IL-6 can promote the synthesis of NGF in astrocytes (Kossmann et al., 1996). Moreover, Loddick et al. (1998) have reported that IL-6 administration reduces brain damage after ischemia. The decreased IL-6 mRNA levels observed in our study may therefore be an early event setting the stage for subsequent cell death cascades.

Decreased gene expression for reparative proteins including Ref-1 and SOD1 was also observed in TUNEL-positive neurons at $12 \mathrm{hr}$ after injury. Ref-1 is a nuclear enzyme involved in DNA repair and activation of transcription factors (Xanthoudakis et al., 1994). After hypoxic ischemia, a decrease in Ref-1 protein was found to precede DNA fragmentation in hippocampal neurons (Walton et al., 1997). The decrease in SOD1 mRNA in these neurons early after the injury may also represent the loss of an important enzyme known to protect the brain from the lethal effects of superoxide anions released after brain trauma. Although no changes were observed in bcl-2 or bcl- $x_{1}$ mRNAs at 12 hr after injury, a decrease in bax mRNA was observed in injured neurons. The decreased expression of bax, a proapoptotic molecule, and the change in the bcl-2/bax ratio may suggest a neuroprotective response by these neurons.

The expression profiles for many genes were observed to return to baseline levels by $24 \mathrm{hr}$ after injury. Gene expression for bcl- $\mathrm{x}_{1}$, however, was significantly decreased. This member of the bcl-2 family has been shown to have antiapoptotic functions (Parsadanian et al., 1998), and a decrease in bcl- $x_{1}$ mRNA may promote apoptosis in injured neurons. In addition, expression of the proapoptotic member bax increased in these same neurons. Previously, Raghupathi et al. (1997) reported an increase in bax mRNA in the cortex $3 \mathrm{~d}$ after lateral FP injury. Because there is a marked increase in the number of apoptotic cells in the contused cortex at $24 \mathrm{hr}$ after injury (Conti et al., 1998), the decrease in bcl- $x_{1}$ combined with an increase in bax mRNA may act as a trigger for apoptosis in injured cortical neurons after TBI.

No differences in the expression of caspase- 3 were observed although increased caspase- 3 mRNA has been shown in cytosolic extracts from injured brain regions $24 \mathrm{hr}$ after TBI using RT-PCR (Yakovlev et al., 1997). The relative abundance of caspase-2, which is homologous to caspase-3, was found to be increased in TUNEL-positive cortical neurons at $24 \mathrm{hr}$ after injury. Caspase-2 has been shown to induce apoptosis in several cell lines (Kumar et al., 1994), and upregulation of caspase- 2 mRNA has been reported after ischemia (Kinoshita et al., 1997). In contrast to caspase-3, caspase-2 has been shown to be an initiator rather than an executor of apoptosis. For example, in response to apoptotic stimuli, caspase- 2 expression precedes the expression of caspase- 3 
(Harvey et al., 1997). Furthermore, because caspase-2 is localized in the nucleus, it is likely responsive to nuclear damage such as DNA fragmentation. The upregulation of caspase- 2 mRNA coupled with the downregulation of bcl- $x_{1}$ in TUNEL-positive neurons exhibiting a nonapoptotic morphology suggests that these events may occur early in apoptosis.

The differential patterns of gene expression in TUNELpositive cortical neurons at 12 versus $24 \mathrm{hr}$ after injury provide a molecular fingerprint of events associated with cell death after TBI. The decrease in mRNAs at $12 \mathrm{hr}$ after injury for many genes subserving a potential neuroprotective function may contribute to cell death by depriving the cell of endogenous neuroprotective factors. The increases in caspase- 2 and bax mRNAs coupled with a downregulation of bcl- $x_{1}$ at $24 \mathrm{hr}$ after injury suggest the initiation of a possible apoptotic program. Whether these differential gene expression patterns reflect (1) a temporal sequence of an ongoing cell death process or (2) the existence of two separate populations of phenotypically identical cells with different cell death processes is not known. Nevertheless, the molecular profiles of TUNEL-positive neurons at both of these time points suggest that therapeutic targets for pharmacological intervention should be designed with these patterns in mind. Although "cocktail" therapy for treatment of TBI is not a new concept, our data empirically support this notion and provide several putative targets for therapeutic intervention. Such use of expression profiling from a biological system to guide the selection or development of therapeutic interventions is called transcript-aided drug design (Eberwine et al., 1995). Our results suggest that it may be beneficial to intervene early after TBI to prevent or compensate for the downregulation in mRNAs encoding endogenous neuroprotective factors in addition to supplying antiapoptotic therapies. The interrelationships among many of the mRNAs examined underscore the importance of investigating multiple, rather than single, transcripts in damaged neurons after TBI. The information gained from molecular fingerprints of damaged neurons can provide a more accurate account of molecular events in TBI pathology and may suggest multiple and novel avenues for therapy.

\section{REFERENCES}

Adams JH, Graham DI, Gennarelli TA (1983) Head injury in man and experimental animals: neuropathology. Acta Neurochir Suppl (Wien) 32:15-30.

Blaha GR, Raghupathi RR, Saatman K, McIntosh TK 2000 Brain derived neurotrophic factor administration after traumatic brain injury in the rat does not protect against behavioral or histological deficits. Neuroscience, in press.

Bramlett HM, Dietrich WD, Green EJ, Busto R (1997) Chronic histopathological consequences of fluid-percussion brain injury in rats: effects of post-traumatic hypothermia. Acta Neuropathol (Berl) 93:190-199.

Brandoli C, Sanna A, De Bernardi MA, Follesa P, Brooker G, Mocchetti I (1998) Brain-derived neurotrophic factor and basic fibroblast growth factor downregulate NMDA receptor function in cerebellar granule cells. J Neurosci 18:7953-7961.

Clark RS, Chen J, Watkins SC, Kochanek PM, Chen M, Stetler RA, Loeffert JE, Graham SH (1997) Apoptosis-suppressor gene bcl-2 expression after traumatic brain injury in rats. J Neurosci 17:9172-9182.

Clark RS, Kochanek PM, Chen M, Watkins SC, Marion DW, Chen J, Hamilton RL, Loeffert JE, Graham SH (1999) Increases in bcl-2 and cleavage of caspase- 1 and caspase- 3 in human brain after head injury. FASEB J 8:813-821.

Colicos MA, Dash PK (1996) Apoptotic morphology of dentate gyrus granule cells following experimental cortical impact injury in rats: possible role in spatial memory deficits. Brain Res 739:120-131.

Conti AC, Raghupathi R, Trojanowski JQ, McIntosh TK (1998) Exper- imental brain injury induces regionally distinct apoptosis during the acute and delayed post-traumatic period. J Neurosci 18:5663-5672.

Cortez SC, McIntosh TK, Noble LJ (1989) Experimental fluid percussion brain injury: vascular disruption and neuronal and glial alterations. Brain Res 482:271-282.

Courtney MJ, Akerman KE, Coffey ET (1997) Neurotrophins protect cultured cerebellar granule neurons against the early phase of cell death by a two-component mechanism. J Neurosci 17:4201-4211.

Crino PB, Trojanowski JQ, Dichter MA, Eberwine J (1996) Embryonic neuronal markers in tuberous sclerosis: single-cell molecular pathology. Proc Natl Acad Sci USA 93:14152-14157.

Dash PK, Moore AN, Dixon CE (1995) Spatial memory deficits, increased phosphorylation of the transcription factor CREB, and induction of the AP-1 complex following experimental brain injury. J Neurosci 15:2030-2039.

DeKosky ST, Goss JR, Miller PD, Styren SD, Kochanek PM, Marion D (1994) Upregulation of nerve growth factor following cortical trauma. Exp Neurol 130:173-177.

Dietrich WD, Alonso O, Mordecai RB, Globus YT, Ginsberg MD (1994) Post-traumatic brain hypothermia reduces histopathological damage following concussive brain injury in the rat. Acta Neuropathol (Berl) 87:250-258.

Dixon CE, Flinn P, Bao J, Venya R, Hayes RL (1997) Nerve growth factor attenuates cholinergic deficits following traumatic brain injury in rats. Exp Neurol 146:479-490.

Eberwine J, Yeh H, Miyashiro K, Cao Y, Nair S, Finnell R, Zettel M, Coleman P (1992) Analysis of gene expression in single live neurons. Proc Natl Acad Sci USA 89:3010-3014.

Eberwine J, Crino PB, Dichter M (1995) Single-cell mRNA amplification: implications for basic and clinical neuroscience. The Neuroscientist 1:200-211.

Ferrand-Drake M, Wieloch T (1999) The time-course of DNA fragmentation in the choroid plexus and the CA1 region following transient global ischemia in the rat brain. The effect of intra-ischemic hypothermia. Neuroscience 93:537-549.

Gavrieli Y, Sherman Y, Ben-Sasson S (1992) Identification of programmed cell death in situ via specific labeling of nuclear DNA fragmentation. J Cell Biol 119:493-501.

Gorter JA, Petrozzino JJ, Aronica EM, Rosenbaum DM, Opitz T, Bennett MV, Connor JA, Zukin RS (1997) Global ischemia induces downregulation of GluR2 mRNA and increases AMPA receptormediated $\mathrm{Ca}^{2+}$ influx in hippocampal CA1 neurons of gerbil. J Neurosci 17:6179-6188.

Goss JR, O'Malley ME, Zou L, Styren SD, Kochanek PM, DeKosky ST (1998) Astrocytes are the major source of nerve growth factor upregulation following traumatic brain injury in the rat. Exp Neurol 149: 301-309.

Harvey NL, Butt AJ, Kumar S (1997) Functional activation of Nedd2/ ICH-1 (Caspase-2) is an early process in apoptosis. J Biol Chem 272:13134-13139.

Hayes RL, Yang K, Raghupathi R, McIntosh TK (1995) Changes in gene expression following traumatic brain injury in the rat. J Neurotrauma 12:779-790.

Hicks RR, Soares HD, Smith DH, McIntosh TK (1996) Temporal and spatial characterization of neuronal injury following lateral-fluid percussion brain injury in the rat. Acta Neuropathol (Berl) 91:236-246.

Hicks RR, Li C, Zhang L, Dhillon H, Prasad MR, Seroogy KB (1999) Alterations in BDNF and trkB mRNA levels in the cerebral cortex following experimental brain trauma in rats. J Neurotrauma 16:501-510.

Kinoshita M, Tomimoto H, Kinoshita A, Kumar S, Noda M (1997) Up-regulation of the Nedd 2 gene encoding an ICE/Ced-3-like cysteine protease in the gerbil brain after transient global ischemia. J Cereb Blood Flow Metab 17:507-514.

Kossmann T, Hans V, Imhof HG, Trentz O, Morganti-Kossmann MC (1996) Interleukin-6 released in human cerebrospinal fluid following traumatic brain injury may trigger nerve growth factor production in astrocytes. Brain Res 713:143-152.

Kotapka MJ, Gennarelli TA, Graham DI, Adams JH, Thibault LE, Ross DT, Ford I (1991) Selective vulnerability of hippocampal neurons in acceleration-induced experimental head injury. J Neurotrauma $8: 247-258$.

Kotapka MJ, Graham DI, Adams JH, Gennarelli TA (1994) Hippocampal pathology in fatal human head injury without high intracranial pressure. J Neurotrauma 11:317-324. 
Kumar S, Kinoshita M, Noda M, Copeland NG, Jenkins NA (1994) Induction of apoptosis by the mouse Nedd2 gene, which encodes a protein similar to the product of the Caenorhabditis elegans cell death gene ced-3 and the mammalian IL-1 $\beta$-converting enzyme. Genes Dev $8: 1613-1626$.

Kume T, Kouchiyama H, Kaneko S, Maeda T, Kaneko S, Akaike A, Shimohama S, Kihara T, Kimura J, Wada K, Koizumi S (1997) BDNF prevents NO mediated glutamate cytotoxicity in cultured cortical neurons. Brain Res 756:200-204.

Loddick SA, Turnbull AV, Rothwell NJ (1998) Cerebral interleukin-6 is neuroprotective during permanent focal cerebral ischemia in the rat. J Cereb Blood Flow Metab 18:176-179.

Lowenstein DH, Thomas MJ, Smith DH, McIntosh TK (1992) Selective vulnerability of dentate hilar neurons following traumatic brain injury: a potential mechanistic link between head trauma and disorders of the hippocampus. J Neurosci 12:4846-4853.

Lowenstein DH, Gwinn RP, Seren MS, Simon RP, McIntosh TK (1994) Increased expression of mRNA encoding calbindin-D28K, the glucoserelated proteins, or the $72 \mathrm{kDa}$ heat-shock protein in three models of acute CNS injury. Mol Brain Res 22:299-308.

McIntosh TK, Vink R, Noble L, Yamakami I, Fernyak S, Faden AI (1989) Traumatic brain injury in the rat: characterization of a lateral fluid percussion model. Neuroscience 28:233-244.

Melcher T, Maas S, Herb A, Sprengel R, Seeburg P, Higuchi M (1996) A mammalian RNA editing enzyme. Nature 379:464.

Morganti-Kossmann MC, Lenzlinger PM, Hans V, Stahel P, Csuka E, Ammann E, Stocker R, Trentz O, Kossmann T (1997) Production of cytokines following brain injury: beneficial and deleterious for the damaged tissue. Mol Psychiatry 2:133-136.

Morikawa E, Mori H, Kiyama Y, Mishina M, Asano T, Kirino T (1998) Attenuation of focal ischemic brain injury in mice deficient in the epsilon1 (NR2A) subunit of NMDA receptor. J Neurosci 18:9727-9732.

Nakamura M, Raghupathi R, Merry DE, Scherbel U, Saatman KE, McIntosh TK (1999) Overexpression of bcl-2 is neuroprotective after experimental brain injury in transgenic mice. J Comp Neurol 412:681-692.

Napieralski JA, Raghupathi R, McIntosh TK (1999) The tumorsuppressor gene, p53, is induced in injured brain regions following experimental traumatic brain injury. Mol Brain Res 71:78-86.

Nibuya M, Nestler EJ, Duman RS (1996) Chronic antidepressant administration increases the expression of cAMP response element binding protein (CREB) in rat hippocampus. J Neurosci 16:2365-2372.

O’Dell DM, Raghupathi R, Crino PB, Eberwine J, McIntosh TK (1998) Amplification of mRNAs from single, fixed, TUNEL-positive cells. Biotechniques 25:566-570.

Parsadanian AS, Cheng Y, Keller-Peck CR, Holtzman DM, Snider WD (1998) $\mathrm{Bcl}-\mathrm{x}_{1}$ is a regulator for postnatal CNS neurons. J Neurosci 18:1009-1019.

Pellegrini-Giampietro DE, Zukin RS, Bennett MV, Cho S, Pulsinelli WA (1992) Switch in glutamate receptor subunit gene expression in CA1 subfield of hippocampus following global ischemia in rats. Proc Natl Acad Sci USA 89:10499-10503.

Raghupathi R, Welsh FA, Lowenstein DH, Gennarelli TA, McIntosh TK (1995) Regional induction of $c$-fos and heat-shock protein-72 mRNA following fluid-percussion brain injury in the rat. J Cereb Blood Flow Metab 15:467-473.

Raghupathi R, Strauss KI, Krajewski S, Reed JC, McIntosh TK (1997) Regional alterations in the expression of $\mathrm{Bcl}-2$ and $\mathrm{Bcl}-\mathrm{x}$ proteins and Bax mRNA following experimental brain injury in the rat. J Cereb Blood Flow Metab 17:S494.

Raghupathi R, Fernandez SC, Murai H, Trusko SP, Scott RW, Nishioka WK, McIntosh TK (1998) BCL-2 overexpression attenuates cortical cell loss after traumatic brain injury in transgenic mice. J Cereb Blood Flow Metab 18:1259-1269.

Rink A, Fung K, Trojanowski JQ, Lee V, Neugebauer E, McIntosh TK (1995) Evidence of apoptotic cell death after experimental traumatic brain injury in the rat. Am J Pathol 147:1575-1583.

Roux PP, Colicos MA, Barker PA, Kennedy TE (1999) p75 neurotrophin receptor expression is induced in apoptotic neurons after seizure. J Neurosci 19:6887-6896.

Rump A, Sommer C, Gass P, Bele S, Meissner D, Kiessling M (1996) Editing of GluR2 RNA in the gerbil hippocampus after global cerebral ischemia. J Cereb Blood Flow Metab 16: 1362-1365.

Schabitz WR, Schwab S, Spranger M, Hacke W (1997) Intraventricular brain-derived neurotrophic factor reduces infarct size after focal cerebral ischemia in rats. J Cereb Blood Flow Metab17:500-506.

Shieh PB, Hu SC, Bobb K, Timmusk T, Ghosh A (1998) Identification of a signaling pathway involved in calcium regulation of BDNF expression. Neuron 20:727-740.

Sinson G, Voddi M, McIntosh TK (1995) Nerve growth factor administration attenuates cognitive but not neurobehavioral motor dysfunction or hippocampal cell loss following fluid-percussion brain injury in rats. J Neurochem 65:2209-2216.

Sinson G, Perri BR, Trojanowski JQ, Flamm ES, McIntosh TK (1997) Neurotrophin infusion improves cognitive deficits and decreases cholinergic neuronal cell loss and apoptotic cell death following experimental traumatic brain injury. J Neurosurg 86:511-518.

Smith DH, Chen X-H, Pierce JES, Wolf JA, Trojanowski JQ, Graham D, McIntosh TK (1997) Progressive atrophy and neuron death for one year following brain trauma in the rat. J Neurotrauma 14:715-727.

Tao X, Finkbeiner S, Arnold DB, Shaywitz AJ, Greenberg ME (1998) $\mathrm{Ca}^{2+}$ influx regulates BDNF transcription by a CREB family transcription factor-dependent mechanism. Neuron 20:709-726.

Tuunanen J, Lukasiuk K, Halonen T, Pitkanen A (1999) Status epilepticus-induced neuronal damage in the rat amygdaloid complex: distribution, time-course and mechanisms. Neuroscience 94:473-495.

Walton M, Sirimanne E, Williams C, Gluckman P, Dragunow M (1996) The role of the cyclic AMP-responsive element binding protein (CREB) in hypoxic-ischemic brain damage and repair. Mol Brain Res 43:21-29.

Walton M, Lawlor P, Sirimanne E, Williams C, Gluckman P, Dragunow M (1997) Loss of Ref-1 protein expression precedes DNA fragmentation in apoptotic neurons. Mol Brain Res 44:167-170.

Walton M, Woodgate A, Muravlev A, Xu R, During MJ, Dragunow M (1999) CREB phosphorylation promotes nerve cell survival. J Neurochem 73:1836-1842.

Whittemore SR, Holets VR, Keane RW, Levy DJ, McKay RD (1991) Transplantation of a temperature-sensitive, nerve growth factorsecreting, neuroblastoma cell line into adult rats with fimbria-fornix lesions rescues cholinergic septal neurons. J Neurosci Res 28:156-170.

Xanthoudakis S, Miao G, Curran T (1994) The redox and DNA repair activities of Ref-1 are encoded by nonoverlapping domains. Proc Natl Acad Sci USA 91:23-27.

Yakovlev AG, Knoblach SM, Fan L, Fox GB, Goodnight R, Faden AI (1997) Activation of CPP32-like caspases contributes to neuronal apoptosis and neurological dysfunction after traumatic brain injury. J Neurosci 17:7415-7424.

Yang K, Mu XS, Xue JJ, Perez-Polo JR, Hayes RL (1995) Regional and temporal profiles of c-fos and nerve growth factor mRNA expression in rat brain after lateral cortical impact injury. J Neurosci Res 42:571-578.

Yang K, Perez-Polo JR, Mu XS, Yan HQ, Xue JJ, Iwamoto Y, Liu SJ, Dixon CE, Hayes RL (1996) Increased expression of brain-derived neurotrophic factor but not neurotrophin-3 mRNA in rat brain after cortical impact injury. J Neurosci Res 44:157-164. 